\title{
The examination of teacher burnout in Turkey: A meta-analysis
}

\author{
Y1lmaz İlker Yorulmaz \\ Muğla Sıtkı Koçman University, Faculty of Education, Muğla, Turkey, \\ yilkeryorulmaz@gmail.com, orcid.org/0000-0003-0934-3942 \\ Yahya Altınkurt \\ Muğla Sitkı Koçman University, Faculty of Education, Muğla, Turkey, \\ yaltinkurt@gmail.com, orcid.org/0000-0002-5750-8847
}
ABSTRACT The purpose of this study is to determine the effect of gender, marital status, subject matter, school type, educational status and seniority variables on teacher burnout. In this regard, a meta-analysis was conducted for the studies on teacher burnout in Turkey. The effect size analyses were performed with 100 studies for gender, 73 for marital status, 17 for subject matter, 15 for school type, 34 for educational status, and 54 for seniority variables. In the study, the possibility of a publication bias was examined. The results of the study conducted with a random effects model revealed that gender, marital status, subject matter, and educational status had a very low effect on teacher burnout, whereas this effect was very low or low for seniority, and low or medium for school type variables. Besides, the variance among the studies for study-type, grade-level, and region moderators did not differ significantly apart from gender variable.

Keywords Teacher, Effect size, Emotional exhaustion, Depersonalization, Personal accomplishment

\section{Türkiye'de görev yapan öğretmenlerin tükenmişliklerinin incelenmesi: Bir meta analiz çalışması}

ÖZ Bu çalışmanın amacı cinsiyet, medeni durum, branş, okul türü, öğrenim durumu ve kıdem değişkenlerinin öğretmen tükenmişliği üzerindeki etkisini belirlemektir. Bu amaç doğrultusunda, öğretmenlerin tükenmişlikleri ile ilgili Türkiye'de yapılan araştırmaların meta analizi yapılmıştır. Araştırmada genel etki büyüklüğü analizleri, cinsiyet değişkeni için 100, medeni durum değişkeni için 73, branş değişkeni için 17, okul türü değişkeni için 15, öğrenim durumu değişkeni için 34 , kıdem değişkeni için ise 54 çalışma ile yapılmıştır. Araştırmada yayın yanlılığının durumu incelenmiştir. Rastgele etkiler modeli ile hesaplanan etki büyüklüğü analizleri sonucunda, cinsiyet, medeni durum, branş ve öğrenim durumunun öğretmen tükenmişliğini çok düşük; kıdemin çok düşük veya düşük, okul türünün ise düşük veya orta düzeyde etkilediği belirlenmiştir. Ayrıca yayın türü, öğretim kademesi ve araştırmanın yapıldığı bölge ara değişkenleri için çalışmalar arası varyans, cinsiyet değişkeni dışında anlamlı olarak farklılaşmamaktadır.

Anahtar

Kelimeler

Ö̆gretmen, Etki büyüklü̆̆̈̈, Duygusal tükenmişlik, Duyarsızlaşma, Kişisel başarı 


\section{INTRODUCTION}

The number of studies conducted on burnout in social sciences has shown a substantial increase since the 1980s. When considered specific to educational organizations, the number of empirical studies on burnout has been increasing with each passing year in Turkey, as well. In addition to this increase, some differences could be encountered among the studies which have been conducted independently from one another. Particularly in terms of demographic variables, the studies regarding teacher burnout have revealed inconsistent results both in the size and the direction of difference between groups. Hereby, meta-analysis studies come into prominence in order to combine the results of such inconsistent studies and hence to attain more generalizable information through combining these results. In this regard, a meta-analysis study investigating teacher burnout in terms of demographic variables was required to be conducted.

The concept of burnout was defined by Bradley (1969) for the first time in literature as a psychological fact observed in employees. With reference to Bradley's (1969) study, Freudenberger (1974) also described burnout with such concepts as depressed mood caused by job-related stress, cynicism, and despondency. The concept of burnout, defined with a clinical view by Freudenberger, was investigated through a socio-psychological perspective by Maslach (Gold \& Roth, 1993). In this sense, Maslach and Jackson (1981) defined burnout as a condition involving physical, emotional and cognitive dimensions, observed mostly in employees working in professions that require face-to-face interaction with individuals.

Expressing the concept of burnout in terms of working life, Maslach and Jackson (1986) have identified that the so-called concept should never be conceptualized in a one-dimensional way, but in a multidimensional structure consisting of emotional exhaustion, depersonalization and personal accomplishment, all of which are empirically related in spite of being conceptually different from one another. First of these dimensions, emotional exhaustion is described as a decrease in energy, intensification of negative feelings, and one's feeling that his emotional resources have been depleted (Maslach \& Jackson, 1984). This refers to a condition of prostration emerging as a result of excessiveness of psychological and emotional demands related to the individual (Huberman \& Vandenberghe, 2009). Together with the fact that this dimension of burnout is the beginning, center, and most important component of burnout (Çelikkaleli, 2011), it is not sufficient to express this phenomenon on its own (Maslach, 2003a). The other dimension of burnout, depersonalization, is individuals' demonstrating unfeeling behaviors and attitudes towards whom they serve (Maslach \& Jackson, 1986). This dimension comes into prominence due to the fact that employees behave the individuals they serve as if they were objects. Thereby, depersonalization is regarded as a strategy to cope with the emotional exhaustion (Lewin \& Sager, 2007). As to the third dimension of burnout, reduced personal accomplishment refers to a gradually emerging failure an individual feels for his job (Huberman \& Vandenberghe, 2009; Maslach \& Jackson, 1984). According to Maslach (2003b), emotional exhaustion is considered as a cause of depersonalization, along with depersonalization as a reason of reduced personal accomplishment. That's why, emotional exhaustion is asserted to cause the perception of reduced personal accomplishment together with the mediation effect of depersonalization (Lewin \& Sager, 2007). Hence, this aforementioned three-dimensional structure is frequently utilized in order to define the burnout in literature.

Just like in all organizations where human relations are intensive, burnout is regarded as a problem field in educational organizations, as well. Considering that teaching profession is regarded as one of the professions requiring devotion, emotional labor, and strong intrinsic values (Yorulmaz, Altınkurt, \& Y1lmaz, 2015), it might be asserted that teachers have a disadvantageous position in depleting their emotional resources. In this respect, teachers might be claimed to experience burnout in most phases of their working lives. In literature, there are many studies identifying that organizational or social factors have an impact on revealing burnout. These studies indicate that organizational discrimination (Çelik, 2011), mobbing (Alkan, 2011; Ergel, 2014), undesirable student behaviors (Hastings \& Bham 2003; Özdemir, 2009), and external control (Byrne, 1994; Huberman, 1993; Sürgen, 2014) enhance teacher burnout whereas organizational commitment (Akgül, 2014), organizational trust (Çağlar, 2011), organizational justice and positive organizational climate (Çakır, 2009), effective and democratic classroom management (Özdemir, 2007; Tümkaya, 2005), and perceived social support (Karataş, 2009) reduce it. 
When examined in terms of personal factors, studies demonstrate that job satisfaction (Diri, 2015; Kılıç \& Yazıc1, 2012; Umay, 2015), occupational professionalism (Çelik, 2015), professional competence (Çelikkaleli, 2011), self-efficacy perception (Friedman, 2003), and positive personal characteristics (Y1lmaz, 2014) decrease teacher burnout, while anxiety for authority use (Hoşgörür, \& Apikoğlu, 2013), and extensive anger conditions (Ekinci, 2013) increase burnout. These studies have indicated that personal characteristics of teachers sometimes enhance burnout whereas they occasionally reduce burnout and its effects. Especially demographic features are frequently given place in such studies with the assumption that personal factors might be determinants on a concept like burnout. Hereby, the effect of such demographic variables as gender, marital status, subject matter, school type, educational status, and seniority on burnout is aimed to be determined in many studies, the results of which are inconsistent in terms of both in the size and the direction of difference between groups. In such a critical matter, the existence of such inconsistent results might complicate the determination of the primary reasons of teacher burnout (Purvanova \& Muros, 2010). From this perspective, a meta-analysis study investigating teacher burnout in terms of demographic variables has been required to be conducted to identify whether demographic variables are the real determinants of teacher burnout and to produce generalizable and up-to-date information.

In literature, there are various meta-analysis studies regarding the burnout of employees working apart from educational organizations (Alarcon, Eschleman, \& Bowling, 2009; Alarcon, 2011; Lee, Kuo, Chien, \& Wang, 2016; Maricuţoiu, Sava, \& Butta, 2016; You, Huang, Wang, \& Bao, 2015) and at educational organizations (Aloe, Amo, \& Shanahan, 2013; Aloe, Shisler, Norris, Nickerson, \& Rinker, 2014; Edmonson, 2000a; Halbesleben, 2006; Yorulmaz, Çolak, \& Altınkurt, 2017). These studies are oriented at determining the relationships between burnout and various individual or organizational variables. However, the number of meta-analysis studies aiming at determining the effect of demographic variables on the burnout of employees is limited. In these studies, it was determined that gender (Purvanova, \& Muros, 2010), seniority, and age (Brewerd \& Shaphard, 2004) had a low effect on burnout. Similarly, the meta-analysis studies examining the burnout of employees in educational organizations (Kış, 2014, 2015) indicated that gender and marital status had a very low effect on educational stakeholders' (teachers, administrators, supervisors or academicians) burnout.

When considering teachers specifically, it was reached a limited number of meta-analyses examining the burnout in terms of demographic variables. In Weng's (2004) doctoral dissertation, gender, marital status, educational status, seniority, grade level, age, and service time at the current school were determined to have a very low effect on burnout. Additionally, Edmonson's (2000a, 2000b) studies revealed that gender, seniority, and age had a low effect on burnout. The studies with reference to Turkish context also indicate that gender and marital status variables had a very low or low effect on teacher burnout (Çoğaltay, Anar, \& Karadăg 2017; Doğuyurt, 2013). However, these studies are limited mostly to gender and marital status variables. In this regard, the purpose of this study is to determine the effect of gender, marital status, subject matter, school type, educational status, and seniority variables on teacher burnout with its recent findings. In accordance with this general purpose, the questions to what level the aforementioned variables have an effect on emotional exhaustion, depersonalization and reduced personal accomplishment of teachers, and how the moderator effects of study-type, grade level and region variables on the effect sizes computed for the aforementioned variables were sought a response.

\section{METHODOLGY}

In this study, the effect of gender, marital status, subject matter, school type, educational status, and seniority variables on teacher burnout in Turkey was identified with a meta-analysis design. Metaanalysis is a statistical method to combine the data of several independent studies with the aim of drawing overall conclusions based on a pooled data (Jak, 2015).

\section{Data Collection Procedure}

First, a literature review by searching ULAKBIM, Google Academic, EBSCOhost, Web of Science, and Higher Education Council's Thesis Center of Turkey (HEC) with such keywords "burnout, emotional exhaustion, depersonalization, (reduced) personal accomplishment and Maslach" and their Turkish equivalents was performed in January 2016. For the theses with restricted-access in HEC, their authors 
and supervisors were tried to be reached. In this regard, a total of 118 articles, 169 master's theses, and 11 doctoral dissertations were obtained. In cases where articles were reproduced from theses, theses were included in the meta-analysis due to including more data. After examining the studies obtained through the databases, some specific criteria were determined for the inclusion of the studies in the metaanalysis. These criteria were as follows: 1) Master's theses, doctoral dissertations or articles were required to be published between the years 2005 to 2015. 2) The studies should be oriented at determining the burnout of pre-school, elementary, lower and upper secondary teachers working in Turkey. 3) The data of the primary studies should be collected with Maslach Burnout Inventory (MBI) and be including findings regarding emotional exhaustion, depersonalization, and reduced personal accomplishment dimensions. 4) The findings of the studies should provide sample size, arithmetic mean, standard deviation, $\mathrm{t}$ or $p$-values or the other statistics required for computation of the effect sizes. 5) The studies should provide the $p$-value in case non-parametric statistics are used in the related findings. The third criterion related to MBI was not a criterion at the beginning of the study. However, it was not possible to obtain a total score through MBI and its dimensions were not empirically fitted with other measurement tools being used to determine the burnout. Moreover, among 298 studies examined, only in 19 studies, the burnout was measured with a data collection instrument except for MBI. That's why, the data's being collected with MBI was decided to be an inclusion criterion.

\section{Coding the Studies}

Before computing effect sizes, a coding form was created for determining the characteristic of any obtained studies and for excluding the studies with inappropriate data. The coding form provided information about authors, publication/completion years, subjects, designs (qualitative, quantitative, mixed, theoretical), regions conducted, sample groups and sizes, developers and validity proofs of data collection instruments, and the grouping and availability of data related to gender, marital status, subjectmatter, school type, educational status and seniority variables. Through this coding key, studies not meeting the inclusion criteria were determined. In this regard, out of 298 researches in terms of all independent variables examined for the meta-analysis, 7 were excluded thanks to having a qualitative design, 2 to having a theoretical design, and 5 to having a mixed design. In addition, 105 of them were excluded as their sample were not compatible with the inclusion criteria. Out of the remained 179 researches, 79 were excluded for gender, 106 for marital status, 162 for subject matter, 164 for school type, 145 for educational status, and 125 for seniority variable since they did not include data concerning the relevant variables. Meeting the inclusion criteria, 100 studies for gender, 73 for marital status, 17 for subject matter, 15 for school type, 34 for educational status, and 54 for seniority variables were determined to be included in the meta-analysis. Thereafter, a second coding key was prepared, which was comprised of data on the sample sizes, arithmetic means, standard deviations, $t$ and $p$ values of the included studies. Then, the findings were combined through meta-analysis.

\section{Heterogeneity}

In the meta-analysis, heterogeneity tests were conducted prior to computing effect sizes. The heterogeneity of the combined effect sizes is mostly determined with the Q test. In what level the Q value is required to be is identified through the test for null hypothesis with the distribution of $\chi^{2}$ (chisquare) and degree of freedom (k-1) (Borenstein, Hedges, Higgins, \& Rothstein, 2009). If the Q exceeds the critical $\chi^{2}$ value based on the degree of freedom and a specified level of significance, then, the effect sizes are identified to be heterogeneous (Card, 2011). However, the Q statistics and significance test is not able to explain the level of heterogeneity. On the other hand, $I^{2}$ value is interpreted as heterogeneity ratio of the total variance among effect sizes (Higgins \& Thompson, 2002; Huedo-Medina, SánchezMeca, Marín-Martínez, \& Botella 2006) and is not directly influenced by the number of studies in metaanalysis (Borenstein et al., 2009; Cooper, Hedges, \& Valentine 2009) when compared to the Q statistics. For this reason, the $\mathrm{I}^{2}$ value was used as another criterion for identifying the heterogeneity level. $\mathrm{I}^{2}$ values' equal to or lower than $25 \%$ was interpreted as low, equal to $50 \%$ as medium, and equal to or higher than $75 \%$ as a high level of heterogeneity (Cooper et al., 2009; Higgins \& Thompson 2002; Huedo-Medina et al., 2006; Pigott, 2012). 


\section{Model Selection}

Before the computation of effect sizes in the meta-analysis, one of the fixed or random effects models is selected. Based on a homogeneity assumption, fixed effects model assumes that all studies included in meta-analysis share a common (true) effect size, which implies that all factors influencing the effect sizes are presumed as the same and there is no variance among all studies (Borenstein et al., 2009). If the mean of the effect sizes is computed based on the fixed effects model, it is asserted that the variance among studies stems from the sampling error (Pigott, 2012). In the case when the random effects model, which is based on a heterogeneity assumption, is selected for the computation of effect sizes, it is presumed that true effect sizes vary from one study to the next (Higgins \& Green, 2008). The purpose of the random effects model, when compared to the fixed effects model, is not to estimate one true effect, but to estimate the mean of a distribution of effects (Borenstein et al., 2009). With regards to the model selection in the meta-analysis, Borenstein et al. (2009) suggest using random effects model if the included studies are selected from the published literature. Moreover, it is stated by Başol (2016) that the use of random effects model is more appropriate when the included studies vary in terms of design, scope, sample and examined variables. Furthermore, it is suggested to make an a-priori decision about model selection in such cases. Considering all of these, the heterogeneity tests were performed to provide proof regarding heterogeneity, but the effect sizes were computed based on the random effects model. The analyses within the scope of this current study were performed through comprehensive metaanalysis software.

\section{Publication Bias}

In the study, the possibility of a publication bias was also examined before computing the effect sizes. Publication bias refers to the presumption that studies finding null (absence of statistically significant effect) or negative (statistically significant effect in opposite direction expected) results are less likely to be published than studies finding positive effects (statistically significant effects in expected direction) (Card, 2011). Publication bias above a specific level influences the mean effect size to be computed and lead it to seem higher than it is (Borenstein et al., 2009). However, meta-analyses are required to include all studies conducted in the related subject in order for synthesized studies to present a reliable level of information. With this in mind, all studies within the frame of the inclusion criteria were tried to be reached, and the possibility of a publication bias was examined using funnel plots, Orwin's Fail-Safe N analysis, Duval and Tweedie's Trim and Fill, and Egger's regression test. Funnel plots concerning the effects of all variables on teacher burnout were examined, and the funnel plots related to the effect of gender variable on emotional exhaustion (EE), depersonalization (DP) and (reduced) personal accomplishment (PA) of teachers were exemplified in Figure 1.

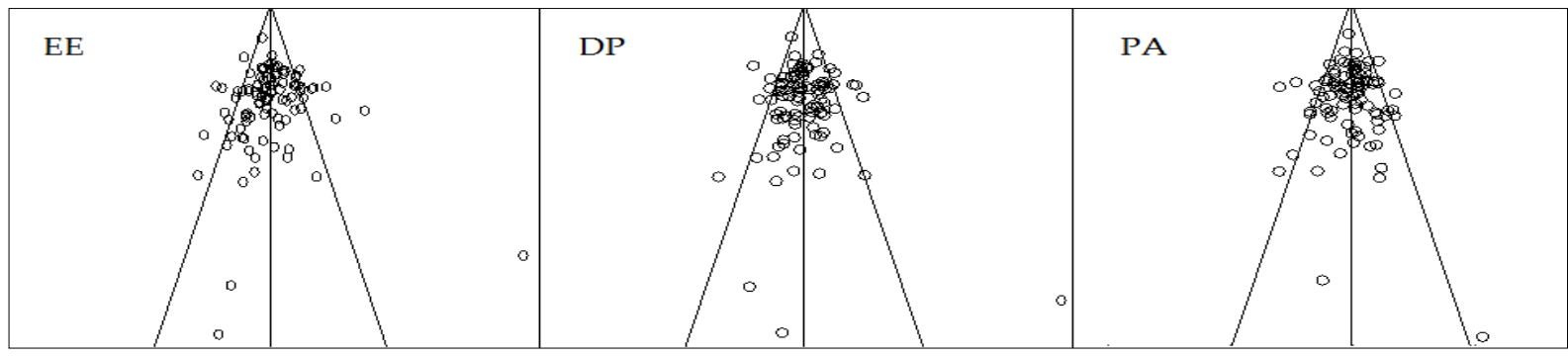

Figure 1. Funnel plots related to the effect of gender on EE, DP, and PA of teachers

When the funnel plots were examined, it was seen that the studies were nearly symmetrically scattered around the vertical line signifying the general effect size and the studies were mostly accumulated in the upper part of the funnel plots. The funnel plots visually expressed that there was no publication bias. Nevertheless, these visual expressions were statistically supported by Orwin's fail-safe $\mathrm{N}$ analysis, Duval and Tweedie's trim and fill, and Egger's regression test, as well. The results of these tests are indicated below in Table 1. 
Table 1.

The results of publication bias tests

\begin{tabular}{|c|c|c|c|c|c|}
\hline \multirow[b]{2}{*}{ Variable } & & \multirow{2}{*}{$\begin{array}{l}\text { Orwin's Fail-Safe N } \\
\text { Studies Required } \\
\text { (for -/+ .01 S.M.D) }\end{array}$} & \multicolumn{2}{|c|}{ Duval and Tweedie } & \multirow[b]{2}{*}{ Egger's Test $(p)$} \\
\hline & & & Trimmed Studies & Observed/Filled & \\
\hline \multirow{3}{*}{ Gender } & $\mathrm{EE}$ & 578 & 19 & $.068(.123)$ & .853 \\
\hline & $\mathrm{DP}$ & 699 & 15 & $-.074(-.031)$ & .230 \\
\hline & PA & 74 & 7 & $-.016(-.041)$ & .307 \\
\hline \multirow{3}{*}{ Marital Status } & $\mathrm{EE}$ & 126 & 1 & $-.019(-.017)$ & .398 \\
\hline & DP & 369 & 0 & $-.059(-.059)$ & .865 \\
\hline & PA & 135 & 7 & $-.027(-.053)$ & .599 \\
\hline \multirow{3}{*}{ Subject Matter } & $\mathrm{EE}$ & 27 & 2 & $-.017(-.033)$ & .175 \\
\hline & DP & 2 & 1 & $.037(.012)$ & .084 \\
\hline & PA & 71 & 0 & $.049(.049)$ & .773 \\
\hline \multirow{3}{*}{ School Type } & $\mathrm{EE}$ & 441 & 0 & $.205(.205)$ & .073 \\
\hline & $\mathrm{DP}$ & 336 & 2 & $.158(.223)$ & .162 \\
\hline & PA & 534 & 2 & $.307(.402)$ & .488 \\
\hline \multirow{3}{*}{ Educational Status } & $\mathrm{EE}$ & 123 & 0 & $-.021(-.021)$ & .078 \\
\hline & $\mathrm{DP}$ & 110 & 5 & $-.039(-.072)$ & .149 \\
\hline & PA & 66 & 2 & $-.042(-.068)$ & .508 \\
\hline \multirow{3}{*}{ Seniority } & $\mathrm{EE}$ & 60 & 14 & $-.001(-.119)$ & .281 \\
\hline & $\mathrm{DP}$ & 419 & 13 & $.119(.012)$ & .182 \\
\hline & PA & 8 & 0 & $-.012(-.012)$ & .927 \\
\hline
\end{tabular}

According to Table 1, Orwin's fail-safe $\mathrm{N}$ analysis revealed that it was not necessary to include more studies in the meta-analysis in order to reduce the standardized mean difference (S.M.D) under the "trivial" +/-.01 value. However, Orwin's fail-safe $\mathrm{N}$ analysis did not provide sufficient proof in terms of subject matter variable, especially for DP, and of seniority variable, especially for PA. For this reason, the results of Orwin's test were supported by Duval and Tweedie's trim and fill analysis and Egger's regression tests. According to Duval's test, when the researches leading to an asymmetry in the funnel plots were trimmed, the new (filled) effect sizes did not considerably differ from the observed effect sizes, which refers to the absence of a publication bias in the meta-analysis. Furthermore, the results of Egger's regression test were not significant ( $p>.05)$ in terms of all variables, which verified the absence of a publication bias in the meta-analysis. After determining that there was no publication bias in the study, effect size computations were performed.

\section{Data Analysis}

In the study, Cohen's $d$ coefficient was used for the effect size computations. In all computations regarding the effect sizes, 95\% confidence level was presumed. The effect size classification with regards to Cohen's $d$ coefficient was as follows (Cohen, 1988): $d<.20$ (low effect); .20<d<.50 (medium effect); $.50<\mathrm{d}<.80$ (high effect). However, effect sizes lower than .10 were considered as a very low effect (Yılmaz, Altınkurt, \& Yildırım 2015).

In the study, women teachers were considered as experimental group and male teachers as control group for gender variable; married as experimental and single as control group for marital status variable; class teachers as experimental and subject teachers as control group for subject matter variable; teachers working at public schools as experimental and teachers at private schools as control group for school type variable, teachers with 10 years or less seniority as experimental and teachers with 11 years or more seniority as control group for seniority variable, and teachers with undergraduate (BA) degree as experimental and teachers with graduate (MA or Ph.D.) degree as control group for educational status variable. In terms of all variables, positive effects were presumed to be in the direction of the experimental group, while negative effects in the direction of the control group. Among the included studies, seniority was classified in various ways such as 5 years of intervals (5 years or less, 6-10 years, 11-15 years, 16-20 years) and 10 years of intervals (1-10 years, 11-20 years). Similarly, educational status was classified in different ways such as MA graduate, Ph.D. graduate, and graduate (both for MA and Ph.D.). Since it was not possible to separate the seniority in 10 years of intervals or transform them into 5 years of intervals, seniority was classified as 10 years or less and 11 years or more seniority. In a 
similar way, MA graduate and Ph.D. graduate teachers were combined and considered as graduate teachers.

In terms of the researches considered for inclusion in the meta-analysis, the number of studies which investigate the difference between groups for the grade-level variable is very limited. In this regard, the characteristics of the included studies' sample groups were examined and the moderator effects of the grade-level, region, and study-type variables on the effect sizes computed for gender, marital status, subject matter, school type, educational status, and seniority were determined through the Q test. Moderators are independent variables presumed to have a possible impact on the findings and are used in meta-analyses for determining the level of such impact on findings (Card, 2011). Therefore, the impacts of study-type (article, thesis), grade-level (pre-school; elementary; lower secondary; primary and lower secondary; upper secondary; primary, lower and upper secondary), and region (Mediterranean, Aegean, Marmara, Central Anatolia, Black Sea, Eastern Anatolia, Southeastern Anatolia, and researches conducted on more than one region) moderators on the effect sizes computed for the aforementioned variables were identified in the study.

\section{FINDINGS}

The purpose of this study was to determine the effect of gender, marital status, subject matter, school type, educational status and seniority variables on teacher burnout. In this regard, the effects of aforementioned variables on the emotional exhaustion (EE), depersonalization (DP), and reduced personal accomplishment (PA) of teachers were examined. Tables below show the results of heterogeneity tests and effect size computations for these variables.

Table 2.

The effect of gender on teacher burnout

\begin{tabular}{ccccccccccc}
\hline & $\mathrm{k}$ & $\mathrm{n}$ & $\mathrm{ES}_{\text {avr }}$ & $p$ & $\mathrm{z}$ & $\mathrm{Q}$ & $\mathrm{I}^{2}$ & $\mathrm{~S}_{\text {error }}$ & $\mathrm{ES}_{\text {low }}$ & $\mathrm{ES}_{\text {up }}$ \\
\hline $\mathrm{EE}$ & 100 & 29094 & .068 & .000 & 3.092 & 269.080 & 63.208 & .021 & .024 & .107 \\
$\mathrm{DP}$ & 99 & 28481 & -.074 & .000 & -3.575 & 249.190 & 60.673 & .021 & -.115 & -.034 \\
$\mathrm{PA}$ & 98 & 28337 & -.016 & .428 & -.792 & 240.369 & 59.645 & .021 & -.057 & -.024 \\
\hline
\end{tabular}

k: Number of studies included in the meta-analysis; $n$ : Total sample size, ESarr: Average effect size;

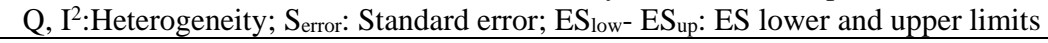

According to Table 2, Q statistics indicated that the included studies were heterogeneous in terms of all three dimensions $(\mathrm{p}=.00)$. Being the other criterion for heterogeneity, I2 values also verified that the included studies had a higher than middle level of heterogeneity for EE, DP, and PA. According to the results of the meta-analysis comprised of 100 studies for EE, 99 for DP and 98 for PA, the effect size of gender variable, computed with the random effects model, on EE was .068 ( $\mathrm{p}<.05)$, on DP -.074 ( $\mathrm{p}<.05)$, on PA -.016 ( $p>.05)$. The computed values identified that the effect of gender on teacher burnout was very low. Although these effects were very low, they revealed that female teachers experienced more emotional exhaustion when compared to males, while male teachers experienced depersonalization and (reduced) personal accomplishment more than females.

Table 3.

The effect of marital status on teacher burnout

\begin{tabular}{ccccccccccc}
\hline & $\mathrm{k}$ & $\mathrm{n}$ & $\mathrm{ES}_{\text {avr }}$ & $p$ & $\mathrm{z}$ & $\mathrm{Q}$ & $\mathrm{I}^{2}$ & $\mathrm{~S}_{\text {error }}$ & $\mathrm{ES}_{\text {low }}$ & $\mathrm{ES}_{\text {up }}$ \\
\hline $\mathrm{EE}$ & 72 & 19298 & -.019 & .518 & -.647 & 207.082 & 65.231 & -.029 & -.076 & .038 \\
$\mathrm{DP}$ & 70 & 18611 & -.059 & .087 & -1.712 & 265.153 & 73.600 & .034 & -.126 & .008 \\
$\mathrm{PA}$ & 71 & 18930 & -.027 & .242 & -1.171 & 121.356 & 41.495 & .023 & -.071 & .018 \\
\hline
\end{tabular}

According to Table 3, Q statistics revealed that the included studies were heterogeneous in terms of all three dimensions $(\mathrm{p}=.00)$. I2 values also approved that the included studies had close to a high level of heterogeneity for EE and DP, and close to a medium level of heterogeneity for PA. According to the results of the meta-analysis comprised of 72 studies for EE, 70 for DP, and 71 for PA, the effect size of marital status variable on EE was -.019 ( $\mathrm{p}>.05$ ), on DP -.059 ( $\mathrm{p}>.05$ ), and on PA -.027 ( $\mathrm{p}>.05)$. The computed values identified that these effects were very low. Even though these effects were very low, 
they indicated that single teachers experienced more emotional exhaustion, depersonalization and (reduced) personal accomplishment than married teachers.

Table 4.

The effect of subject matter on teacher burnout

\begin{tabular}{ccccccccccc}
\hline & $\mathrm{k}$ & $\mathrm{n}$ & $\mathrm{ES}_{\text {avr }}$ & $p$ & $\mathrm{z}$ & $\mathrm{Q}$ & $\mathrm{I}^{2}$ & $\mathrm{~S}_{\text {error }}$ & $\mathrm{ES}_{\text {low }}$ & $\mathrm{ES}_{\text {up }}$ \\
\hline $\mathrm{EE}$ & 17 & 5061 & -.017 & .686 & -.404 & 30.022 & 46.706 & .042 & -.100 & .066 \\
$\mathrm{DP}$ & 16 & 4693 & .037 & .603 & -.358 & 71.833 & 79.118 & .070 & -.101 & .174 \\
$\mathrm{PA}$ & 16 & 4657 & .049 & .434 & .782 & 57.168 & 73.162 & .063 & -.074 & .173 \\
\hline
\end{tabular}

According to Table 4, Q statistics identified that the included studies were heterogeneous in terms of all three dimensions $(\mathrm{p}=.00)$. Besides, I2 values verified that the included researches had close to a medium level of heterogeneity for EE, and a high level for DP and PA. According to the results of the metaanalysis comprised of 17 studies for EE and 16 for DP and PA, the effect size of subject matter variable on EE was -.017 ( $p>.05)$, on DP .037 ( $p>.05$ ), and on PA .049 ( $p>.05)$. The computed effect sizes revealed that these effects were very low. However, these effects indicated that subject teachers experienced emotional exhaustion more than class teachers had, while class teachers experienced depersonalization and (reduced) personal accomplishment more than subject teachers.

Table 5.

The effect of school type on teacher burnout

\begin{tabular}{ccccccccccc}
\hline & $\mathrm{k}$ & $\mathrm{n}$ & $\mathrm{ES}_{\text {avr }}$ & $p$ & $\mathrm{z}$ & $\mathrm{Q}$ & $\mathrm{I}^{2}$ & $\mathrm{~S}_{\text {error }}$ & $\mathrm{ES}_{\text {low }}$ & $\mathrm{ES}_{\text {up }}$ \\
\hline $\mathrm{EE}$ & 15 & 3786 & .205 & .033 & 2.138 & 70.700 & 80.198 & .096 & .017 & .392 \\
$\mathrm{DP}$ & 15 & 3786 & .158 & .091 & 1,691 & 67.031 & 79.114 & .093 & -.025 & .340 \\
$\mathrm{PA}$ & 15 & 3786 & .307 & .017 & 2.386 & 129.626 & 89.200 & .129 & .055 & .558 \\
\hline
\end{tabular}

According to Table 5, Q statistics indicated that the included studies were heterogeneous in terms of all three dimensions $(\mathrm{p}=.00)$. Along with this, $\mathrm{I} 2$ values approved that the included studies were heterogeneous at a high level for EE, DP, and PA. According to the results of the meta-analysis comprised of 15 studies for EE, DP, and PA, the effect size of school type variable on EE was .205 $(p<.05)$, on DP .158 ( $p>.05)$, and on PA .307 ( $p<.05)$. The computed effect sizes identified that these effects were medium for EE and PA and low for DP. Furthermore, these effects revealed that the teachers working at public schools experienced emotional exhaustion, depersonalization, and (reduced) personal accomplishment more than the teachers working at private schools.

Table 6.

The effect of educational status on teacher burnout

\begin{tabular}{ccccccccccc}
\hline & $\mathrm{k}$ & $\mathrm{n}$ & $\mathrm{ES}_{\text {avr }}$ & $p$ & $\mathrm{z}$ & $\mathrm{Q}$ & $\mathrm{I}^{2}$ & $\mathrm{~S}_{\text {error }}$ & $\mathrm{ES}_{\text {low }}$ & $\mathrm{ES}_{\text {up }}$ \\
\hline $\mathrm{EE}$ & 34 & 8374 & -.021 & .678 & -.415 & 69.326 & 52.399 & .050 & -.120 & .078 \\
$\mathrm{DP}$ & 34 & 8374 & -.039 & .288 & -1.062 & 37.897 & 12.921 & .036 & -.110 & .033 \\
$\mathrm{PA}$ & 34 & 8374 & -.042 & .420 & -.806 & 74.205 & 55.529 & .052 & -.144 & .060 \\
\hline
\end{tabular}

According to Table 6, Q statistics revealed that the included researches were heterogeneous in terms of all three dimensions $(p=.00)$. Additionally, $\mathrm{I}^{2}$ values verified that the included studies had close to a high level heterogeneity for EE and PA, a low level heterogeneity for DP. According to the results of the meta-analysis comprised of 34 studies for EE, DP, and PA, the effect size of educational status variable on EE was -.021 ( $p>.05)$, on DP -.039 ( $p>.05)$, and on PA -.042 ( $p>.05)$. The computed values identified that these effects were very low for EE, DP, and PA. Though they were very low, they indicated that the teachers with a graduate degree experienced emotional exhaustion, depersonalization, and (reduced) personal accomplishment more than the teachers with an undergraduate degree.

Table 7.

The effect of seniority on teacher burnout

\begin{tabular}{ccccccccccc}
\hline & $\mathrm{k}$ & $\mathrm{n}$ & $\mathrm{ES}_{\text {avr }}$ & $p$ & $\mathrm{z}$ & $\mathrm{Q}$ & $\mathrm{I}^{2}$ & $\mathrm{~S}_{\text {error }}$ & $\mathrm{ES}_{\text {low }}$ & $\mathrm{ED}_{\text {up }}$ \\
\hline $\mathrm{EE}$ & 54 & 16602 & -.001 & .984 & -.020 & 269.123 & 80.306 & .040 & -.078 & .077 \\
$\mathrm{DP}$ & 51 & 15580 & .119 & .001 & 3.298 & 195.542 & 74.430 & .036 & .048 & .190 \\
$\mathrm{PA}$ & 51 & 15562 & -.012 & .779 & -.280 & 279.425 & 82.106 & .043 & -.097 & .073 \\
\hline
\end{tabular}


Lastly in Table 7, Q statistics refers to a heterogeneity in terms of all dimensions ( $p=.00$ ). $\mathrm{I}^{2}$ values also approved the high level of heterogeneity for EE, DP, and PA. As to the results of the meta-analysis comprised of 54 studies for EE, 51 for DP, and PA, the effect size of seniority on EE was -.001 ( $p>.05)$, on DP .119 ( $p<.05)$, and on PA -.012 ( $p>.05)$. The computed effects identified that these effects were very low for EE and PA and low for DP. However, these values revealed that the teachers having 11 years or more seniority experienced more emotional exhaustion and (reduced) personal accomplishment than the teachers having 10 years or less seniority, while the teachers having 10 years and less seniority experienced more depersonalization when compared to the teachers having 11 years or more seniority. The very last purpose of this study was to determine the moderator effect of study-type, grade-level, and region variables on the effect sizes computed for gender, marital status, subject matter, school type, educational status, and seniority. The results of moderator analyses identified that the variance among studies for study-type, grade-level and region moderators did not differ significantly except for gender variable $(p>.05)$. Furthermore, the variance among studies for study-type moderator according to gender variable was statistically significant in only depersonalization $(\mathrm{Q}=4.057, p<.05)$. The studies' being thesis or article changed the effect of gender variable on depersonalization of teachers. The effect of articles $(d:-.152)$ was higher than thesis $(d:-.052)$.

\section{DISCUSSION and CONLUSIONS}

The current study intended to determine the effect of gender, marital status, subject matter, school type, educational status, and seniority variables on teacher burnout by a meta-analysis of the studies conducted in the educational organizations. Meeting the inclusion criteria, 100 studies for gender, 73 for marital status, 17 for subject matter, 15 for school type, 34 for educational status, and 54 for seniority variable were included in the meta-analysis. The increase in the number of studies about teacher burnout as of the year 2005 was found as remarkable. 27 publications per year in average between 2005 and 2015 were identified to be conducted with regards to burnout. Almost all of these studies were in a quantitative design. Along with these, a few studies in qualitative, theoretical and mixed designs were encountered in literature. The total sample size of this meta-analysis study ranged from 28.337 to 29.094 for gender, 18.611 to 19.298 for marital status, 4.657 to 5.061 for subject matter, and 15.562 to 16.602 for seniority. The total sample size was identified as 8.374 for educational status and 3.786 for school type. Furthermore, the data of the included studies were determined to be obtained from all geographical regions of Turkey, which was considered to contribute the generalizability of the data.

As a result of this study, the effect sizes of gender variable were determined to be very low. Though these effects were very low, female teachers were found to experience more emotional exhaustion than males whereas male teachers had more depersonalization and reduced personal accomplishment feeling when compared to females. In related literature, such a difference between gender groups is explained by the fact that females have a higher possibility to work in the professions requiring face-to-face interaction and males need more social support due to their lower numbers at schools (Gold \& Roth, 1993; Maslach \& Jackson, 1985). However, the number of female and male teachers are approximately equal in Turkey according to the 2015/2016 statistics of the Ministry of National Education-MNE (2016). Therefore, such a difference between gender groups might be explained by societal stereotypes specific to gender. According to Altınkurt and Yilmaz (2012), both the sexist perspective dominating in the society and also the maternity and child minding roles imposed on females are some of the invisible obstacles they encounter in working life. Moreover, sexist values related to females are also adopted by females along with the males, which complicates the progress of females in the organizations (Zel, 2002). Such factors might lead females to experience more emotional exhaustion. Besides, Hofstede (2005) claims that Turkey has a collectivist culture demonstrating feminine characteristics. In such collectivist cultures, the relations are warm and intimate, but the emphasis on individualism and professionalism is quite less. In such cultures with a paternalistic social structure as Turkey, the fact that teaching profession is perceived as a female job might be a reason for males to experience more depersonalization and perception of reduced personal accomplishment.

When the included studies were examined singly, the effect sizes were identified as high only in a few studies in terms of emotional exhaustion (Aydemir, 2014; Deryakulu, 2005; Kurtoğlu, 2011; Sezer, 2012), depersonalization (Bağc1 \& Karagül, 2013; Deryakulu, 2005; Kurtoğlu, 2011), and reduced personal accomplishment (Aslan, 2009; Deryakulu, 2005; Kurtoğlu, 2011); and as medium in a few 
studies (Arslan \& Aslan, 2014; İnce, 2014; Yeğin, 2014; Yıldız, 2011) for all three dimensions. However, the effect sizes were low or very low in the most of the studies. Similar meta-analysis studies examining teacher burnout (Çoğaltay et al., 2017; Doğuyurt, 2013; Edmonson, 2000b; Weng, 2004) also identified that gender had a very low or insignificant effect on teacher burnout.

Analyses also revealed that grade-level and region moderators had not a significant impact on the effect sizes computed for gender variable. However, study-type moderator was found to have a significant impact on the effect size computed for gender variable in terms of depersonalization. The effect size of articles was higher than theses. Considering the effect size of the studies on a single basis, a thesis (Deryakulu, 2005) and an article (Kurtoğlu, 2011) whose effect sizes were the highest were deducted and the moderator analysis was repeated. Then, the impact of the moderator variable disappeared $(\mathrm{Q}=2.97, p>.05)$. Nevertheless, the effect size of the articles was still higher than the theses. The reason for this finding might be that the possibility to publish studies with statistically significant differences in journals is higher (Card, 2011) or it might also stem from the perceptions of researchers in this aspect. Considering this aspect, the inclusion of theses into the meta-analysis might have provided more reliable information by decreasing the publication bias. However, study-type, grade level, and region moderators did not have an effect on teacher burnout in terms of marital status, subject matter, school type, educational status, and seniority variables.

In the meta-analysis study, the effect sizes of marital status were identified as very low. In spite of their low level, single teachers had more emotional exhaustion, depersonalization and reduced personal accomplishment when compared to married teachers. The reason for this finding might be that single teachers are generally given more responsibility when tasks are shared in schools within the scope of Turkey's social structure. This finding might also be resulting from the fact that single teachers have more individual responsibility outside the working life and their work-life balance is weaker when compared to married teachers. On the other hand, the favorable family experiences of married teachers might reduce their burnout. When the included studies were investigated one by one, the effect sizes were identified to be medium or high in a few studies in terms of emotional exhaustion (Ataç, 2015; Aydemir, 2014; Bağc1 \& Karagül, 2013; İğneler, 2015), depersonalization (Altınkurt, Ertürk, \& Yılmaz, 2015; Diri, 2015; İğneler, 2015), and reduced personal accomplishment (İnce, 2014; Kurtoğlu, 2011; Öztürk, 2015). Nevertheless, the effect sizes were low or very low in most of the included studies. The meta-analysis studies investigating burnout in specific to teachers (Çoğaltay et al., 2017; Doğuyurt, 2013; Weng, 2004) also indicated that marital status had a very low effect on burnout.

According to the meta-analysis study, the effect sizes of subject matter variable were also very low for all three dimensions. What was remarkable was that subject teachers had more emotional exhaustion when compared to class teachers, while class teachers had more depersonalization and reduced personal accomplishment when compared to subject teachers. The reason why subject teachers experienced more emotional exhaustion might be that they work with students at an older age group and they deal with problems such as adolescence. In addition, class teachers' experiencing relatively lower emotional exhaustion might result from that they have more intimate and friendly educational environment due to the close relations with their students. Nonetheless, class teachers' higher reduced personal accomplishment might arise from that they are regarded to be responsible for their students' achievements or failures on their own since they carry out nearly all the courses of their students. This condition might reveal their depersonalization correspondingly. However, there is a great need for further studies to determine the reasons for this finding. Any meta-analysis or meta-evaluation studies investigating teacher burnout in terms of subject matter could not be broached. That's why the discussion of the research results is carried out with the included studies. Out of these, the effect sizes were determined to be high or medium in a few studies in terms of emotional exhaustion (Arslan \& Aslan 2014; Seferoğlu, Yıldız, \& Avc1-Yücel, 2014), depersonalization (Çelik, 2011; Karataş, 2009), and reduced personal accomplishment (Çelik, 2011) whereas it was at a low or very low level in most of the included studies.

In terms of school type variable, the effect sizes were low for depersonalization and medium for emotional exhaustion and reduced personal accomplishment. The teachers working at public schools had more emotional exhaustion, depersonalization, and reduced personal accomplishment when compared to the teachers working at private school. When the included studies were investigated, the effect sizes were low or very low in a few studies (Ayvaz, 2015; Y1lmaz, 2010) and medium or high in most of the studies (Bümen, 2010; Kuvan, 2009; Otacioğlu, 2008) in terms of emotional exhaustion. 
For depersonalization, effect sizes were medium or high in a few studies (Ayvaz, 2015; Kuvan, 2009; Otacıoğlu, 2008) and low or very low in most of the studies (Uğurlu, 2012; Y1ldız, 2011; Y1lmaz, 2010). In terms of reduced personal accomplishment, the effect sizes were low or very low in a few studies (Uğurlu, 2012; Yalçın, 2011) and medium or high in the most of the included studies (Ayvaz, 2015; Bayramoğlu, 2008; Karataş, 2009). The meta-analysis study conducted by Doğuyurt (2013) also stated that school type had a low level effect on teacher burnout and, similar to the current study, the teachers at public schools experienced more burnout than the teachers at private schools. This finding is remarkable since teachers at public schools would have been expected to experience less burnout due to their job assurance when compared to the teachers at private school. The reason for this finding might be that the teachers working at public schools in Turkey are exposed to more political repressions and patronage relations when compared to teachers in the private schools. Another reason might be that the appointment of administrators and promotion of teachers are not always carried out based on their qualifications. In this sense, Hofstede (2005) states that Turkey is a society whose power distance is quite high, the characteristics of which are centralization and non-equal distribution of the power. According to Hofstede $(1980,1983)$, the perception of high power distance might cause the inequalities in the society to be regarded as a normally and naturally adopted phenomenon. Hence, the administrators' not requiring legitimization when using power might as well be a reason for teachers at public schools to experience more burnout. However, the discussions are related to the foresight of the researchers. Hereby, conducting further studies regarding the reasons for this finding might contribute substantially to the related literature.

Educational status is another demographic variable whose effect on teacher burnout was investigated. The effect of educational status on teacher burnout was very low. Most of the included studies also identified that these effects were at a low or very low level except a few studies which asserted that the effect sizes were high or medium terms of emotional exhaustion (Çelik, 2011; Seferoğlu et al., 2014; Umay, 2015), depersonalization (Ataç, 2015; Aydemir, 2014; Umay, 2015), and reduced personal accomplishment (Cinay, 2015; Iliman-Püsküllüoğlu, 2015; Sürgen, 2014). The results of this metaanalysis identified that the teachers with a graduate degree had more emotional exhaustion, depersonalization, and reduced personal accomplishment than the teachers with an undergraduate degree. What was remarkable was that the teachers with a graduate degree had higher reduced personal accomplishment. This might result from that the more the teachers have higher awareness, the more they notice their insufficiencies. Furthermore, that having a graduate education in Turkey does not reflect on teachers' careers and income status at an adequate level (or not at all) might be a reason for the increase of depersonalization. In also Weng's (2004) meta-analysis study conducted on teachers, educational status was determined to have a very low effect on teacher burnout, but unlike this current meta-analysis, it was identified that the more educational status increased, the more depersonalization also increased but emotional exhaustion and reduced personal accomplishment decreased.

Finally, the effect size of seniority was very low for emotional exhaustion and low for depersonalization and reduced personal accomplishment. The teachers with 11 years or more seniority had more emotional exhaustion and reduced personal accomplishment when compared to the teachers with 10 years or less seniority. However, the difference in terms of emotional exhaustion was very close to the point of indifference. The teachers having 10 years or less seniority had more depersonalization than the teachers having 11 years and more seniority. The teachers with 11 years or more seniority had more reduced personal accomplishment was a striking finding since experienced teachers would have been expected to have this emotion lower than their less experienced colleagues. A similar result was obtained for the teachers with a graduate degree, as well. The reason for this finding might be that experienced teachers' level of awareness is relatively higher, or the other way round, they consider themselves insufficient in accessing information and using information technologies. Nevertheless, it is obvious that further studies are needed to be conducted. Besides, the fact that teachers with 10 years or less seniority experienced more depersonalization might result from that they feel their expectations do not correspond with the reality and they could not comply with the organizational structure yet. Moreover, teachers' being exposed to ideological and political repressions, ever-changing educational systems, the absence of a strong performance evaluation system, and these teachers' having relatively higher awareness might be another reason for the teachers in this seniority group to experience more depersonalization. In also the different meta-analysis studies examining the burnout in specific to teachers (Edmonson, 2000a; Weng, 2004), seniority variable was identified to have a low or very low effect on burnout. When the 
included studies were examined one by one, the effect sizes were high or medium in a few studies in terms of emotional exhaustion (Çolakoğlu, 2014; Diri, 2015), depersonalization (Altınkurt et al., 2015; Iliman-Püsküllüoğlu, 2015), and reduced personal accomplishment (Ayvaz, 2015; Çelik, 2015; Kurtoğlu, 2011) of teachers, and low or very low in most of the included studies.

When the results of the study are evaluated as a whole, it could be identified that gender, marital status, subject matter, educational status, and seniority have a very low, and school type variable has a low effect on teacher burnout. These results mostly coincide with the results of meta-analysis studies oriented at the effect of demographic variables on teacher burnout. Burnout draws attention as one of the topics on which the highest number of studies is conducted in the recent years. However, researchers' deficiencies in reporting the necessary statistics for meta-analyses reduce the generalizability of metaanalysis studies. In this regard, researchers are required to be more attentive in reporting the necessary statistics in order for their studies to be included in further meta-analysis studies. All in all, it has been identified through this study that the effect of demographic variables on teacher burnout is limited. In further studies, researchers are recommended to conduct meta-analyses oriented at determining the relationships between different personal or organizational variables and the burnout of teachers, or the effect of these variables on the burnout of teachers.

\section{Acknowledgement}

This study has been produced from the master's thesis of the first author supervised by Assoc. Prof. Dr. Yahya Altınkurt and granted by Muğla Sitkı Koçman University Scientific Research Projects Coordination Office with Project Number: 15/248.

\section{REFERENCES}

Akgül, Z. (2014). A study of the relations between organizational commitment and burnout according to mathematics teachers' perceptions (Master's thesis). Cumhuriyet University, Sivas.

Alarcon, G. (2011). A meta-analysis of burnout with job demands, resources, and attitudes. Journal of Vocational Behavior, 79(2), 549-562.

Alarcon, G., Eschleman, K. J., \& Bowling, N. A. (2009). Relationships between personality variables and burnout: A meta-analysis. Work \& Stress, 23(3), 244-263.

Alkan, E. (2011). The effect of mobbing behaviors on burnout of physical education and sports teachers (Master's thesis). Balıkesir University, Balıkesir.

Aloe, A. M., Amo, L. C., \& Shanahan, M. E. (2013). Classroom management self-efficacy and burnout: A multivariate meta-analysis. Educational Psychology Review, 26(1), 101-126.

Aloe, A. M., Shisler, S. M., Norris, B. D., Nickerson, A. B., \& Rinker, T. W. (2014). A multivariate meta-analysis of student misbehavior and teacher burnout. Educational Research Review, 12, 30-44.

Altınkurt, Y., \& Yılmaz, K. (2012). Being a female school administrator in Turkey: Views of teachers and administrators. Energy Education Science and Technology Part B: Social and Educational Studies, 4(4), 2227-2238.

Altınkurt, Y., Ertürk, A., \& Y1lmaz, İ. (2015). The relationship between psychological capital and burnout levels of teachers. Journal of Teacher Education and Educators, 4(2), 166-187.

Arslan, G., \& Aslan, G. (2014). Measurement of special education teachers' burnout levels (Tokat example). Journal of Educational Sciences Research, 4(2), 49-66.

Aslan, N. (2009). The occupational burnout level of the teachers working primary schools in Kars (Master's thesis). Kafkas University, Kars.

Ataç, H. D. (2015). The investigation of burnout level according to the audit focus in primary school teachers (Master's thesis). Haliç University, İstanbul.

Aydemir, S. (2014). Investigation of the relationship between the perceptions of guidance counselors on the leadership style of their directors and their burnout levels (Master's thesis). Maltepe University, İstanbul.

Ayvaz, U. (2015). Examination of physical education teachers' levels of burnout in terms of specific variables (Master's thesis). Yeditepe University, İstanbul.

Bağc1, H., \& Karagül, S. (2013). Burnout levels of Turkish teachers. Mehmet Akif Ersoy University Journal of Social Science Institute, 5(8), 184-193.

Başol, G. (2016). "Response letter to editor: In response to the letter to editor by Dinçer (2016): Concerning "A content analysis and methodological evaluation of meta-analyses on Turkish samples". International Journal of Human Sciences, 13(1), 1395-1401. 
Bayramoğlu, F. (2008). An application on the teachers who burnout for comparing their level according to different variables in public high schools and private high schools (Master's thesis). Beykent University, İstanbul.

Borenstein, M., Hedges, L. V., Higgins, J. P. T., \& Rothstein, H. R. (2009). Introduction to meta-analysis. UK: Wiley.

Bradley, H. B. (1969). Community-based treatment for young adult offenders. Crime and Delinquency, (15), 359370.

Brewer, E. W., \& Shapard, L. (2004). Employee burnout: A meta-analysis of the relationship between age or years of experience. Human Resource Development Review, 3(2), 102-123.

Bümen, N. (2010). The relationship between demographics, self-efficacy, and burnout among teachers. Eurasian Journal of Educational Research, (40), 16-35.

Byrne, B. M. (1994). Burnout: Testing for the validity, replication and invariance of causal structure across elementary, intermediate, and secondary teachers. American Education Research Journal (31), 645-673.

Çağlar, Ç. (2011). An examination of teacher's occupational burnout levels in terms of organizational confidence and some other variables. Educational Sciences: Theory \& Practice, 11(4), 1827-1847.

Çakır, T. (2009). The effect of organizational climate and justice on burnout (Master's thesis). Yeditepe University, İstanbul.

Card, N. A. (2011). Applied meta-analysis for social science research: Methodology in the social sciences. New York: Guilford.

Çelik, G. (2011). Organizational discrimination in primary schools and its effects on teacher's burnout levels (Master's thesis). Sakarya University, Sakarya.

Çelik, M. (2015). The relationship between teachers' occupational professionalism and burnout (Master's thesis). Dumlupınar University, Kütahya.

Çelikkaleli, Ö. (2011). Investigation of adult education teachers' burnout and occupational self-efficacy. Mehmet Akif Ersoy University Journal of Social Science Institute, 3(4), 38-53.

Cinay, F. (2015). The relationship between primary school teachers' professional burnout and organizational citizenship behaviors (Master's thesis). Okan University, İstanbul.

Çoğaltay, N., Anar, S., \& Karadağ, E. (2017). The factors affecting teachers' burnout: A meta-analytical study on the effect of gender and marital status. Hacettepe University Journal of Education, 32(3), 695-707.

Cohen, J. (1988). Statistical power analysis for the behavioral sciences (2. ed.). Hillsdale, New Jersey: Lawrence Earlbaum Associates.

Çolakoğlu, İ. (2014). Examination of burnout level of middle school teachers who are studying in music (Master's thesis). İstanbul Aydın-Yıldız Teknik Universities, İstanbul.

Cooper, H., Hedges, L. V., \& Valentine, J. C. (2009). The handbook of research synthesis and meta-analysis (2. ed.). New York: Russell Sage.

Deryakulu, D. (2005). Bilgisayar öğretmenlerinin tükenmişlik düzeylerinin incelenmesi. Eurasian Journal of Educational Research, (19), 35-53.

Diri, S. (2015). The effect to secondary school teachers' job satisfaction to the occupational burnout level (Master's thesis). Adnan Menderes University, Aydin.

Doğuyurt, M. F. (2013). The search of occupational burnout levels of teachers according to some variables: A meta-analysis study (Master's thesis). Gaziosmanpaşa University, Tokat.

Edmonson, S. (2000a). Job burnout among special educators: a meta-analysis (Doctoral Dissertation). Texas A\&M University, Bell \& Howell Information and Learning Company.

Edmonson, S. (2000b). Women and special educator burnout: A research synthesis. Paper presented at the Research on Women and Education Annual Conference, San Antonio, USA.

Ekinci, N. (2013). Investigation the relationship of teachers' expression of anger style and their level of fatigue (Master's thesis). Necmettin Erbakan University, Konya.

Ergel, A. (2014). Preschool teachers are exposed to burnout effect of psychological violence (Master's thesis). Firat University, Elazığ.

Freudenberger, H. J. (1974). Staff burnout. Journal of Social Issues (30), 159-165.

Friedman, I. A. (2003). Self-efficacy and burnout in teaching: The importance of interpersonal-relations efficacy. Social Psychology of Education, 6(3), 191-215.

Gold, Y., \& Roth, R. A. (1993). Teachers managing stress and preventing burnout: The professional health solution. London: Falmer.

Halbesleben, J. R. B. (2006). Sources of social support and burnout: A meta-analytic test of the conservation of resources model. Journal of Applied Psychology, 91(5), 1134-1145.

Hastings, R. P., \& Bham, M. S. (2003). The relationship between student behaviour patterns and teacher burnout. School Psychology International, 24(1), 115-127.

Higgins, J. P., \& Green, S. (Eds.). (2008). Cochrane handbook for systematic reviews of interventions (Vol. 5). UK: John Wiley \& Sons. 
Higgins, J. P., \& Thompson, S. G. (2002). Quantifying heterogeneity in a meta-analysis. Statistics in medicine, 21(11), 1539-1558.

Hofstede, G. (1980). Culture's consequences: International differences in work-related values. CA: Sage.

Hofstede, G. (1983). National cultures revisited. Cross-Cultural Research, 18(4), 285-305.

Hofstede, G. (2005). National culture-Turkey. Retrieved from http://geert-hofstede.com/turkey.html

Hoşgörür, T., \& Apikoglu, S. (2013). Relationship between school administrators' anxiety levels for authority use and burnout levels. Educational Process: International Journal, 2(1-2), 19-35.

Huberman, M. (1993). Burnout in teaching careers. European Education, 25(3), 47-69.

Huberman, M., \& Vandenberghe, R. (2009). Introduction- burnout and the teaching profession. In R. Vandenberghe \& A. M. Huberman (Eds.), Understanding and preventing teacher burnout: A sourcebook of international research and practice. UK: Cambridge University.

Huedo-Medina, T. B., Sánchez-Meca, J., Marín-Martínez, F., \& Botella, J. (2006). Assessing heterogeneity in meta-analysis: Q statistic or I2 index? Psychological Methods, 11, 193-206.

İğneler, K. Ö. (2015). Determining occupational exhaustion level of music teachers: Example of Gaziantep city (Master's thesis). Zirve University, Kahramanmaraş.

Iliman-Püsküllüoğlu, E. (2015). The relationship between school administrators' social capital levels perceived by high school teachers and teachers' burnout levels: Muğla sample (Master’s thesis). Muğla Sitkı Koçman University, Muğla.

İnce, N. B. (2014). A comparison of combination classroom teachers' and single-grade teachers' job satisfaction and burnout levels (Master's thesis). Hacettepe University, Ankara.

Jak, S. (2015). Meta-analytic structural equation modelling. Cham: Springer.

Karataş, H. (2009). The relationship between occupational burnout and multidimensional perceived social support teachers (Master's thesis). Maltepe University, İstanbul.

Kılıç, I., \& Yazıcı, T. (2012). Study of job satisfaction and professional exhaustion of music teachers in fine arts and sport high schools in terms of some variables. Journal of New World Sciences Academy, 7(2), 182-198.

Kış, A. (2014). Marital status differences in burnout among educational stakeholders: A meta-analysis. International Journal of Human Sciences, 11(2), 543-558.

Kış, A. (2015). Gender differences in burnout among educational stakeholders: A meta-analysis (Turkish Case). Ondokuz Mayis University Journal of Faculty of Education, 34(2), 88-106.

Kurtoğlu, Ü. (2011). An evaluation of ELT teachers' vocational burnout according to some variables (Master's thesis). Kafkas University, Kars.

Kuvan, Ö. (2009). Informatic technology teachers problems and their level of being exhausted (Master's thesis). Sakarya University, Sakarya.

Lee, H. F., Kuo, C. C., Chien, T. W., \& Wang, Y. R. (2016). A meta-analysis of the effects of coping strategies on reducing nurse burnout. Applied Nursing Research, 31, 100-110.

Lewin, J. E., \& Sager, J. K. (2007). A process model of burnout among salespeople: Some new thoughts. Journal of Business Research, 60, 1216-1224.

Maricuţoiu, L. P., Sava, F. A., \& Butta, O. (2016). The effectiveness of controlled interventions on employees' burnout: A meta-analysis. Journal of Occupational and Organizational Psychology, 89(1), 1-27.

Maslach, C. (2003a). Job burnout new directions in research and intervention. Current Directions in Psychological Science, 12(5), 189-192.

Maslach, C. (2003b). Burnout-the cost of caring. NJ: Prentice-Hall.

Maslach, C., \& Jackson, S. E. (1981). The measurement of experienced burnout. Journal of Occupational Behavior (2), 99-113.

Maslach, C., \& Jackson, S. E. (1984). Burnout in organizational settings. Applied Social Psychology Annual (5), 133-153.

Maslach, C., \& Jackson, S. E. (1985). The role of sex and family variables in burnout. Sex Roles, 12(7), 837-851.

Maslach, C., \& Jackson, S. E. (1986). Maslach burnout inventory manual. CA: Consulting Psychologist.

MNE. (2016). National education statistics: Formal education, 2015/'16. Ankara: Ministry of National Education.

Otacıoğlu, S. G. (2008). Burnout syndrome among music teachers and triggering factors. Inonu Journal of Faculty of Education, 9(15), 103-116.

Özdemir, T. (2009). The relationship between the undesired student behavior in the classroom and teachers' level of burnout (Doctoral dissertation). Abant İzzet Baysal University, Bolu.

Özdemir, Y. (2007). The role of classroom management efficacy in predicting teacher burnout. World Academy of Science, Engineering and Technology, 1(11), 11-25.

Öztürk, D. (2015). The relationship between school culture and burnout in training organization (Bahçelievler district of research) (Master's thesis). Yeditepe University, İstanbul.

Pigott, T. (2012). Advances in meta-analysis. Chicago: Springer.

Purvanova, R. K., \& Muros, J. P. (2010). Gender differences in burnout: A meta-analysis. Journal of Vocational Behavior, 77(2), 168-185. 
Seferoğlu, S. S., Yildiz, H., \& Avc1-Yücel, Ü. (2014). Teachers' burnout: Indicators of burnout and investigation of the indicators in terms of different variables. Education and Science, 39(174), 348-364.

Sezer, F. (2012). Examining of teacher burnout level in terms of some variables. International Online Journal of Educational Sciences, 4(3), 617-631.

Sürgen, S. (2014). Correlation between class teacher's focus of control and level of burnout (Master's thesis). Balıkesir University, Balıkesir.

Tümkaya, S. (2005). Öğretmenlerin sınıf içi disiplin anlayışları ve tükenmişlikle ilişkisi. Educational Administration: Theory and Practice (44), 549-568.

Uğurlu, M. (2012). The investigation of the relationship between thinking styles and burnout levels of high school teachers (Master's thesis). Necmettin Erbakan University, Konya.

Umay, G. (2015). Job satisfaction and burnout level correlation of psychological consultant \& guidance counselor (Master's thesis). Yeditepe University, İstanbul.

Weng, C. H. (2004). Meta-analysis of teacher burnout in public schools in the United States (Doctoral Dissertation). University of South Dakota, Vermillion.

Yalçın, M. (2011). The relation of burnout level of the educators working in special education with emphatic tendencies and some variances (Master's thesis). Gaziantep University, Gaziantep.

Yeğin, H. İ. (2014). Burnout levels of religious culture and ethics education teachers. Ekev Akademi Dergisi, $58(58), 315-332$.

Y1ldı, E. (2011). Burnout among educators: A research on the guidance counselors (Master's thesis). Sakarya University, Sakarya.

Yilmaz, B. (2010). Investigation of fatigue levels of primary teachers who works at state and private schools (Master's thesis). Uludağ University, Bursa.

Y1lmaz, K. (2014). The relationship between the teachers' personality characteristics and burnout levels. Anthropologist, 18(3), 783-792.

Yılmaz, K., Altınkurt, Y., \& Yildırım, H. (2015). The effects of gender, seniority and subject matter variables on teachers' organizational citizenship behaviors in Turkey: A meta-Analysis. Education and Science, 40(178), 285-304.

Yorulmaz, Y. I., Altınkurt, Y., \& Yılmaz, K. (2015). The relationship between teachers' occupational professionalism and organizational alienation. Educational Process: International Journal, 4(1-2), 31-44.

Yorulmaz, Y. I., Colak, I., \& Altinkurt, Y. (2017). A meta-analysis of the relationship between teachers' job satisfaction and burnout. Eurasian Journal of Educational Research, 71, 175-192.

You, X., Huang, J., Wang, Y., \& Bao, X. (2015). Relationships between individual-level factors and burnout: A meta-analysis of Chinese participants. Personality and Individual Differences, 74, 139-145.

Zel, U. (2002). Perception of female administrators in business and the queen bee syndrome. Turkey Middle East Journal of Public Administration, 35(2), 39-48. 


\section{APPENDIX A}

\section{Studies Included in the Meta-analysis}

Acun, M. (2010). The investigation of the biology teachers occupational burnout levels according to some variables (Master's thesis). Dicle University, Diyarbakır.

Adiloğulları, G. E. (2013). Examination of relation between emotional intelligence levels and professional burnout levels of physical education teachers (Master's thesis). Kahramanmaraş Sütçüimam University, Kahramanmaraş.

Ak, N. (2014). Examining the burnout levels of the teachers teaching at vocational and technical high schools in terms of some variables (Master's thesis). İstanbul Aydın University-Yıldız Teknik University, İstanbul.

Akdağ, A. (2014). The examination of burnout level of teachers working as headmaster in multigrade schools: Adryaman province sample (Master's thesis). Türk Hava Kurumu University, Ankara.

Akgül, Z. (2014). A study of the relations between organizational commitment and burnout according to mathematics teachers' perceptions (Master's thesis). Cumhuriyet University, Sivas.

Akkurt, Z. (2008). Analysis of the burnout levels and satisfaction levels of pre-school teachers (as shown in the Istanbul-Pendik example) (Master's thesis). Selçuk University, Konya.

Akman, B., Taskin, N., Özden, Z., \& Çortu, F. (2010). A study on preschool teachers' burnout. Elementary Education Online, 9(2), 807-815.

Akten, S. (2007). The inspection of occupational burnout level of guidance counselors (Master's thesis). Trakya University, Edirne.

Alkan, M. F. (2014). Burnout level and causes of middle school teachers (Master's thesis). İstanbul Aydın University, İstanbul.

Altınkurt, Y., Ertürk, A., \& Yılmaz, İ. (2015). The relationship between psychological capital and burnout levels of teachers. Journal of Teacher Education and Educators, 4(2), 166-187.

Altunyuva, H. E. (2011). Burnout level of primary school teachers in Elazig city center (Master's thesis). Firat University, Elazığ.

Arıcan, T. (2009). The study of the relation between occupational exhausting in teachers and bureaucracy in school management (Master's thesis). Yeditepe University, İstanbul.

Arikan, S. (2007). The investigation of the burnout levels and reasons of the classroom teachers who are working at the first stage of Muğla centrum primary schools (Master's thesis). Muğla University, Muğla.

Arslan, G., \& Aslan, G. (2014). Measurement of special education teachers' burnout levels (Tokat example). Journal of Educational Sciences Research, 4(2), 49-66.

Aslan, N. (2009). The occupational burnout level of the teachers working primary schools in Kars (Master's thesis). Kafkas University, Kars.

Ataç, H. D. (2015). The investigation of burnout level according to the audit focus in primary school teachers (Master's thesis). Haliç University, İstanbul.

Avşaroğlu, S., Deniz, M. E., \& Kahraman, A. (2005). Teknik öğretmenlerde yaşam doyumu iş doyumu ve mesleki tükenmişlik düzeylerinin incelenmesi. Selçuk University Social Sciences Institute Journal (14), 115-129.

Aydemir, H. (2013). The study of exploring the burnout and life satisfaction levels of teachers who have been working with students with special needs (Master's thesis). Abant İzzet Baysal University, Bolu.

Aydemir, S. (2014). Investigation of the relationship between the perceptions of guidance counselors on the leadership style of their directors and their burnout levels (Master's thesis). Maltepe University, İstanbul.

Ayvaz, U. (2015). Examination of physical education teachers' levels of burnout in terms of specific variables (Master's thesis). Yeditepe University, İstanbul.

Bağc1, H., \& Karagül, S. (2013). Burnout levels of Turkish teachers. Mehmet Akif Ersoy University Journal of Social Science Institute, 5(8), 184-193.

Başören, M. (2005). Examining the level of the exhaustion of the guide teachers according to some variables (Zonguldak example) (Master's thesis). Zonguldak Karaelmas University, Zonguldak.

Bayrak, M. (2014). Job satisfaction and bornout level of primary school teachers (Master's thesis). Gaziantep University, Gaziantep.

Bayramoğlu, F. (2008). An application on the teachers who burnout for comparing their level according to different variables in public high schools and private high schools (Master's thesis). Beykent University, İstanbul.

Biçen, H. (2014). Burnout sendrome in the newly appointed teachers (Master's thesis). Dicle University, Diyarbakir.

Bümen, N. (2010). The relationship between demographics, self-efficacy, and burnout among teachers. Eurasian Journal of Educational Research, (40), 16-35. 
Büyüközkan, A. S. (2012). An investigation of the relationship between teachers' organizational citizenship behaviors and burnout (Master's thesis). Mersin University, Mersin.

Cihan, B. B. (2011). A research on comparison of jop burnout level of physical education teachers working at primary schools in different cities burnout (Master's thesis). Gazi University, Ankara.

Cinay, F. (2015). The relationship between primary school teachers' professional burnout and organizational citizenship behaviors (Master's thesis). Okan University, İstanbul.

Çağlayan, A. (2012). Levels of burnout combined classroom teacher (Master's thesis). Atatürk University, Erzurum.

Çam, Z. (2010). The relation between the mobbing behaviors teachers in elementary schools are exposed to and their burnout levels (Van province example) (Master's thesis). Yüzüncü Y1l University, Van.

Çavuşoğlu, İ. (2005). The levels of relations between burnout levels and some personal variabilities of teachers in industrial vocational high schools (Master's thesis). Abant İzzet Baysal University, Bolu.

Çelebi, E. (2013). The burnout levels of the teachers working at sprecial educational instutitions in Elazig and Malatya city centres and related factors (Doctoral dissertation). Firat University, Elazı̆g.

Çelik, G. (2011). Organizational discrimination in primary schools and its effects on teacher's burnout levels (Master's thesis). Sakarya University, Sakarya.

Çelik, M. (2015). The relationship between teachers' occupational professionalism and burnout (Master's thesis). Dumlupınar University, Kütahya.

Çelikkaleli, Ö. (2011). Investigation of adult education teachers' burnout and occupational self-efficacy. Mehmet Akif Ersoy University Journal of Social Science Institute, 3(4), 38-53.

Çimen, S. (2007). Primary school teachers' burnout levels and perceived self-efficacy beliefs (Master's thesis). Kocaeli University, Kocaeli.

Çolakoğlu, İ. (2014). Examination of burnout level of middle school teachers who are studying in music (Master's thesis). İstanbul Aydın-Yıldız Teknik Universities, İstanbul.

Deryakulu, D. (2005). Bilgisayar öğretmenlerinin tükenmiş̧lik düzeylerinin incelenmesi. Eurasian Journal of Educational Research, (19), 35-53.

Diri, S. (2015). The effect to secondary school teachers' job satisfaction to the occupational burnout level (Master's thesis). Adnan Menderes University, Aydin.

Ekinci, N. (2013). Investigation the relationship of teachers' expression of anger style and their level of fatigue (Master's thesis). Necmettin Erbakan University, Konya.

Erdemoğlu Şahin, D. (2007). Burnout level of the teachers (Master's thesis). Gazi University, Ankara.

Ergel, A. (2014). Preschool teachers are exposed to burnout effect of psychological violence (Master's thesis). Firat University, Elazı̆̆.

Erkul, A. (2014). The vocational burnout levels of vocational high school teachers (Master's thesis). Bahçeşehir University, İstanbul.

Girgin, G. (2010). The investigation of factors affecting the teachers' burnout. Electronic Journal of Social Sciences, 32(32), 32-48.

Gündoğdu, G. B. (2013). A research on career satisfaction and professional burnout levels of class teachers: The case study of Mersin (Master's thesis). Çă̆ University, Mersin.

Güney, B. (2014). The relationship between the leadership features of the administrators in The Medical Vocational High Schools and vocational teachers job satisfaction and feeling exhausted (Master's thesis). İstanbul Sabahattin Zaim University, İstanbul.

Gürbüz, Z. (2008). Professional burnout and job satisfaction levels of preschool teachers who were doing in the region of Kars (Master's thesis). Marmara University, İstanbul.

Güven-Şahinkaya, S. (2013). Primary school teachers school principals occupational burnout educational leader relationship between the detection levels (Master's thesis). Yüzüncü Yıl University, Van.

Harmanda-Demirhan, E. (2011). Analyze on the relation between the exhaustion levels of the preschool education teachers working at Ankara city centre and their assessment on unwanted behaviours in children (Master's thesis). Gazi University, Ankara.

Iliman-Püsküllüoğlu, E. (2015). The relationship between school administrators' social capital levels perceived by high school teachers and teachers' burnout levels: Muğla sample (Master's thesis). Muğla Sitk1 Koçman University, Muğla.

İğneler, K. Ö. (2015). Determining occupational exhaustion level of music teachers: Example of Gaziantep city (Master's thesis). Zirve University, Kahramanmaraş.

İnce, N. B. (2014). A comparison of combination classroom teachers' and single-grade teachers' job satisfaction and burnout levels (Master's thesis). Hacettepe University, Ankara.

Kan, Ü. D. (2008). An analysis of burnout at a group of preschool education teachers. Kastamonu Education Journal, 16(2), 431-438. 
Karacan, A. (2012). An investigation about the level of burnout of the teachers who work with individuals can be trained and taught at the private educational institues: The case of Anatolian side of Istanbul (Master's thesis). Maltepe University, İstanbul.

Karahan, Ş. (2008). The analysis of self-efficacy perception and burnout level of special education school educators (Master's thesis). Marmara University, İstanbul.

Karahan, Ş., \& Balat-Uyanık, G. (2011). The analysis of self-efficacy perception and burnout level of special education school educators. Pamukkale University Journal of Education, 29(29), 1-14.

Karakuş, G. (2008). Investigation of teachers' burnout level in primary and secondary schools in respect of some variables (Master's thesis). Gazi University, Ankara.

Karataş, H. (2009). The relationship between occupational burnout and multidimensional perceived social support teachers (Master's thesis). Maltepe University, İstanbul.

Kaya, T. (2009). The research of exhaustion level of the guidance counselors according to the same various factors (Master's thesis). Beykent University, İstanbul.

Kaymaz, H. (2015). The investigation of professional burnout levels of the teachers who are working in vocational and technical education institutions in Atassehir, Istanbul (Master's thesis). Okan University, İstanbul.

Kılıç, I., \& Yazıcı, T. (2012). Study of job satisfaction and professional exhaustion of music teachers in fine arts and sport high schools in terms of some variables. Journal of New World Sciences Academy, 7(2), 182-198.

Koralay, F. D. (2014). Professional burnout levels of the teachers in primary schools (Master's thesis). Dokuz Eylül University, İzmir.

Koruklu, N., Feyzioğlu, B., Özenoğlu-Kiremit, H., \& Aladağ, E. (2012). Teachers' burnout levels in terms of some variables. Educational Administration: Theory and Practice, 12(3), 1813-1831.

Kurtoğlu, Ü. (2011). An evaluation of ELT teachers' vocational burnout according to some variables (Master's thesis). Kafkas University, Kars.

Kuvan, Ö. (2009). Informatic technology teachers problems and their level of being exhausted (Master's thesis). Sakarya University, Sakarya.

Mumcu, L. (2014). Physical education teachers job satisfaction and burnout levels of investigation (Master's thesis). Karadeniz Teknik University, Trabzon.

Otacioğlu, S. G. (2008). Burnout syndrome among music teachers and triggering factors. Inonu Journal of Faculty of Education, 9(15), 103-116.

Öktem, E. (2009). An investigation of the burnout degrees of primary school teachers in terms of some specific variables (Afyonkarahisar-Sandlkl sample) (Master's thesis). Ege University, İzmir.

Özcan, T. (2008). A study of burnout levels of teachers, attendent in Pendik district, according to some demographic variables (Master's thesis). Yeditepe University, İstanbul.

Özdemir, T. (2009). The relationship between the undesired student behavior in the classroom and teachers' level of burnout (Doctoral dissertation). Abant İzzet Baysal University, Bolu.

Özdemir, Y. (2007). The role of classroom management efficacy in predicting teacher burnout. World Academy of Science, Engineering and Technology, 1(11), 11-25.

Özer, N., \& Beycioglu, K. (2010). The relationship between teacher professional development and burnout. Procedia- Social and Behavioral Sciences, 2(2), 4928-4932.

Özer-Karakaplan, E. (2013). The relation between burnout sendrome and total quality management: An application on primary schools in Adyaman (Master's thesis). Adiyaman University, Adiyaman.

Özipek, A. (2006). The reasons and the level of professional burnout in teachers, work in secondary schools (Master's thesis). Trakya University, Edirne.

Öztürk, A. (2006). Comparative analysis of emotional intelligence job satisfaction and burnout levels of preschool teachers according to some variables (Master's thesis). Selçuk University, Konya.

Öztürk, A., \& Engin, D. M. (2008). Analysis of emotional intelligence job satisfaction and burnout levels of preschool teachers according to some variables. Elementary Education Online, 7(3), 578-599.

Öztürk, D. (2015). The relationship between school culture and burnout in training organization (Bahçelievler district of research) (Master's thesis). Yeditepe University, İstanbul.

Sar1, H. (2010). An analysis of burnout and job satisfaction among Turkish special school headteachers and teachers, and the factors affecting their burnout and job satisfaction. Educational Studies, 30(3), 291-306.

Seçer, İ. (2011). Investigation of burnout levels of psychological counselors with respect to different variables. Sakarya University Journal of Education, 1(2), 16-24.

Seferoğlu, S. S., Yildiz, H., \& Avc1-Yücel, Ü. (2014). Teachers' burnout: Indicators of burnout and investigation of the indicators in terms of different variables. Education and Science, 39(174), 348-364.

Sezer, F. (2012). Examining of teacher burnout level in terms of some variables. International Online Journal of Educational Sciences, 4(3), 617-631.

Soyer, F., Can, Y., \& Kale, F. (2009). Examining the physical education teacher's job satisfaction and the level of exhaustion in aspect of some kinds of variabels. Niğde University Journal of Physical Education and Sport Sciences, 3(3), 259-271. 
Sürgen, S. (2014). Correlation between class teacher's focus of control and level of burnout (Master's thesis). Balıkesir University, Balıkesir.

Şahin, E. (2010). Creativity, professional burnout and life satisfaction of primary school teachers (Master's thesis). Sakarya University, Sakarya.

Şahin, F. (2007). The relatinship between the personal career planning of the teachers the burnout levels of the teachers in education organizations (Master's thesis). Yeditepe University, İstanbul.

Şahin, F., \& Dilek, Ş. (2012). Examining the burnout level of special education teachers working with disabled individuals. Journal of Teacher Education and Educators, 1(2), 275-294.

Tavl1, O. (2009). Examining the relation between problem solving abilities and burnout levels of high school teachers (Master's thesis). Yeditepe University, İstanbul.

Telef, B. B. (2011). The study of teachers' self-efficacy, job satisfaction, life satisfaction and burnout. Elementary Education Online, 10(1), 91-108.

Teltik, H. (2009). The determination of teacher self-efficacy perception between job satisfaction and burnout level correlations for preschool teachers (Master's thesis). Marmara University, İstanbul.

Toplu-Yilmaz, N. (2012). Burnout levels of preschool and primary school teachers (Master's thesis). Adnan Menderes University, Aydin.

Tulunay, Ö. (2010). Primary school teachers' burnout levels on organizational communication and commitment (Master's thesis). Kirıkkale University, Kirıkkale.

Tuna, M., \& Çimen, Z. (2013). The analysis of the burnout level of physical education teachers working in Ankara. Pamukkale Journal of Sport Sciences, 4(2), 60-78.

Türker, P. (2007). The analysis of primary school teachers' perceptions of problem behavior levels according to the socio demographic variants and burnout (Master's thesis). Çukurova University, Adana.

Uğurlu, M. (2012). The investigation of the relationship between thinking styles and burnout levels of high school teachers (Master's thesis). Necmettin Erbakan University, Konya.

Umay, G. (2015). Job satisfaction and burnout level correlation of psychological consultant \& guidance counselor (Master's thesis). Yeditepe University, İstanbul.

Yalçın, M. (2011). The relation of burnout level of the educators working in special education with emphatic tendencies and some variances (Master's thesis). Gaziantep University, Gaziantep.

Yazıc1, K., \& Avc1, E. (2011). Analysis of occupational burnout status of social studies teachers considering several variables. Pegem Journal of Education and Instruction, 1(4), 29-37.

Yeğin, H. İ. (2014). Burnout levels of religious culture and ethics education teachers. Ekev Akademi Dergisi, 58(58), 315-332.

Yetimoğlu, H. İ. (2014). Level living with teachers intimidation investigation of the relationship between levels of burnout: Çekmeköy sample (Master's thesis). Yeditepe University, İstanbul.

Yıldız, E. (2011). Burnout among educators: A research on the guidance counselors (Master's thesis). Sakarya University, Sakarya.

Y1lmaz, B. (2010). Investigation of fatigue levels of primary teachers who works at state and private schools (Master's thesis). Uludağ University, Bursa.

Y1lmaz, T. (2013). The burnout levels of physicial education teachers: Application of Ordu province (Master's thesis). Gazi University, Ankara.

Yiğit, A. (2007). The works satisfaction of the teachers who works in the private educational institutes the searching the level of burnout and the healty of soul in dint of wary changable factors (Master's thesis). Niğde University, Niğde.

Yungul, N. T. (2006). Evaluation of the exhaustion level of school teachers (The case of İstanbul) (Master's thesis). Yeditepe University, İstanbul. 


\section{GENIŞLETILMIŞ TÜRKÇE ÖZET}

\section{Türkiye'de görev yapan öğretmenlerin tükenmişliklerinin incelenmesi: Bir meta analiz çalışması}

1980’li yıllardan itibaren tükenmişlik konusunda sosyal bilimler alanında yapılan çalışmaların sayısı ciddi oranda artış göstermektedir. Eğitim örgütleri özelinde de, Türkiye'de tükenmişlik üzerine yapılan ampirik araştırmaların sayısı gün geçtikçe artmaktadır. Bilgi üretimi noktasındaki bu artış, araştırma sonuçlarının birleştirilmesi gerekliliğini de beraberinde getirmektedir. Ancak, çalışma sayısındaki artı̧̧a rağmen birbirinden bağımsız olarak yürütülen araştırmaların sonuçları arasında farklılıklara rastlanabilmektedir. Özellikle demografik değişkenler açısından, öğretmen tükenmişliği üzerine yapılan çalışmalar, hem gruplar arası farklılığın boyutu hem de yönü konusunda tutarlı olmayan sonuçlar ortaya koymaktadır. Bu tip araştırma sonuçlarının bütünleştirilebilmesi ve bilginin genellenebilirliğine katkı sağlaması noktasında ise meta analiz çalışmaları devreye girmektedir. Bu sebeple, öğretmen tükenmişliğini demografik değişkenler açısından inceleyen bir meta analiz çalışması yapılmasına gereksinim duyulmuştur.

$\mathrm{Bu}$ çalışma ile cinsiyet, medeni durum, branş, okul türü, öğrenim durumu ve kıdem değişkenlerinin öğretmen tükenmişliği üzerindeki etkisinin belirlenmesi amaçlanmıştır. Bu amaç doğrultusunda, tükenmişlik ile ilgili Türkiye'de yapılan araştırmaların meta analizi yapılmıştır. Çalışmada yer alan araştırmalara ulaşmak için ULAKBİM, Google Akademik, EBSCOhost, Web of Science ve YÖK Ulusal Tez Merkezi veri tabanlarından yararlanılmıştır. Bu çerçevede, 118 makale, 169 yüksek lisans ve 11 doktora tezine ulaşılmıştır. Veri tabanlarından elde edilen çalışmalar incelendikten sonra, çalışmaların meta analize dâhil edilmesine ilişkin bazı ölçütler belirlenmiştir. $\mathrm{Bu}$ ölçütler 1) Araştırmaların 2005-2015 yılları arasında tamamlanmış yüksek lisans ve doktora tezleri veya hakemli dergilerde yayınlanmış makaleler olması; 2) Türkiye'de görev yapan okul öncesi, ilkokul, ortaokul, ilköğretim okulu ya da lise öğretmenlerinin tükenmişliklerini belirlemeye yönelik olması; 3) Verilerin "Maslach Tükenmişlik Ölçeği” ile toplanmış olması ve ölçeğin "duygusal tükenmişlik, duyarsılaşma ve kişisel başarısızlık algısı" boyutlarına ilişkin bulguların yer alması; 4) Araştırma bulgularında örneklem büyüklügü, aritmetik ortalama, standart sapma, $\mathrm{t}$ veya $p$ değerlerinin yer alması ya da bunların hesaplanabilmesi için gerekli değerlerin verilmiş olması ve 5) Parametrik olmayan testler yapılmışsa, ilgili bulgulara ait $p$ değerlerinin verilmiş olması şeklindedir.

Meta analiz çalışması dâhil edilme ölçütlerine uygun toplam 114 araştırma ile gerçekleştirilmiştir. Ancak bütün araştırmalarda aynı değişkenler ele alınmadığ için değişkenler açısından meta analize dâhil edilen çalışma sayısı farklıdır. Bu nedenle, araştırmada genel etki büyüklüğü analizleri, cinsiyet değişkeni için 100 , medeni durum değişkeni için 73 , branş değişkeni için 17 , okul türü değişkeni için 15 , öğrenim durumu değişkeni için 34 , kıdem değişkeni için ise 54 çalışma ile yapılmıştır. Araştırmaya dâhil edilen çalışmaların toplam örneklem büyüklükleri tükenmişliğin boyutları açısından, cinsiyet değişkenine göre 28.337 ile 29.094, medeni durum değişkenine göre 18.611 ile 19.298, branş değişkenine göre 4.657 ile 5.061, kıdem değişkenine göre 15.562 ile 16.602 aralığındadır. Öğrenim durumu değişkenine göre 8.374, okul türü değişkenine göre ise 3.786 ' dır.

Meta analize dâhil edilen çalışmalar heterojen yapıdadır. Meta analiz çalışmasında etki değerlerinin hesaplanmasında heterojenlik varsayımına dayanan rastgele etkiler modeli kullanılmıştır. Araştırmada yayın yanlılı̆̆ıın durumu huni saçılım grafikleri, Orwin'in Güvenli N hesaplaması, Duval ve Tweedie'nin Kırpma ve Doldurma testi ve Egger'in doğrusal regresyon testi ile incelenmiştir. Elde edilen değerler, meta analizde yayın yanlılığının olmadığını doğrulamaktadır. Araştırmada, etki değeri hesaplamalarında Cohen'in $d$ katsayısı kullanılmıştır. Etki değerine ilişkin tüm hesaplamalarda güven düzeyi $\% 95$ olarak kabul edilmiştir.

Araştırma sonuçlarına göre, cinsiyet, medeni durum, branş ve öğrenim durumu değişkenleri öğretmen tükenmişliğini çok düşük düzeyde, kıdem değişkeni tükenmişliğin boyutları açısından çok düşük veya düşük düzeyde, okul türü değişkeni ise düşük veya orta düzeyde etkilemektedir. Etkilerin yönü açısından, kadın öğretmenler erkeklere göre daha fazla duygusal tükenmişlik, erkekler ise kadınlardan daha fazla duyarsızlaşma ve kişisel başarısızlık yaşamaktadır. Medeni durum değişkeni açısından, bekâr 
öğretmenlerin tükenmişlikleri evlilere göre daha fazladır. Branş öğretmenleri sınıf öğretmenlerine göre daha fazla duygusal tükenmişlik, sınıf öğretmenleri ise branş öğretmenlerine göre daha fazla duyarsızlaşma ve kişisel başarısızlık yaşamaktadır. Okul türü değişkeni açısından, devlet okullarında görev yapan öğretmenlerin tükenmişlikleri özel okullarda görev yapanlara göre daha fazladır. Öğrenim durumu değişkeni açısından, lisansüstü öğrenim görmüş öğretmenler, lisans mezunu öğretmenlere göre daha fazla tükenmiş̧lik yaşamaktadır. Son olarak kıdem değişkeni açısından elde edilen bulgular, 11 yıl ve üzerinde kıdeme sahip öğretmenlerin 10 yıl ve altında kıdeme sahip öğretmenlere göre daha fazla duygusal tükenmişlik, 10 yıl ve altında kıdeme sahip öğretmenlerin ise 11 yıl ve üzeri kıdeme sahip öğretmenlere göre daha fazla duyarsızlaşma yaşadığını göstermektedir.

Meta analiz çalışmasında cinsiyet, medeni durum, branş, okul türü, öğrenim durumu ve kıdem değişkenlerine göre hesaplanan etki değerlerine, araştırma türü, öğretim kademesi ve araştırmanın yapıldığı yer değişkenlerinin ara değişken etkisi incelenmiştir. Ara değişken analizi sonuçları, meta analize dâhil edilen çalışmaların makale ya da tez olmasının cinsiyet değişkenine göre öğretmenlerin duyarsızlaşmasına ilişkin etki büyüklüğünü değiştirdiğini göstermektedir. Makalelerin etki büyüklüğü tezlerden daha fazladir.

Tükenmişlik, Türkiye'de son yıllarda en fazla sayıda araştırma yapılan konulardan biri olarak dikkat çekmektedir. Ancak, yapılan çalışmalarda, araştırmacıların meta analiz yapılabilmesi için gerekli istatistikleri raporlama konusundaki eksiklikleri meta analiz çalışmalarının genellenebilirliğini düşürmektedir. Bu noktada, araştırmacıların yaptıkları çalışmaların ileride yapılabilecek meta analiz çalışmalarına dâhil edilebilmesi için, gerekli istatistikleri raporlama konusunda daha titiz davranmaları gerektiği düşünülmektedir. Ayrıca, bu araştırma ile demografik değişkenlerin öğretmenlerin tükenmişlikleri üzerindeki etkisinin sınırlı olduğu görülmektedir. $\mathrm{Bu}$ nedenle, bundan sonraki çalışmalarda çeşitli kişisel veya örgütsel değişkenler ile tükenmişlik arasındaki ilişkileri veya bu değişkenlerin tükenmişliğe etkisini belirlemeye yönelik meta analiz çalışmaları yapılması önerilmektedir. 